[Agr. Biol. Chem., Vol. 34, No. 3, p. 473 475, 1970]

\title{
Heterogeneity of Rice Glutelin
}

\author{
By Masatoshi TakedA, Yasunosuke Namba and Yataro Nunokawa \\ Research Institute of Brewing, 2-6-30 Takinogawa, Kita-ku, Tokyo \\ Received July 18, 1969
}

Palminao et al. ${ }^{1 \prime}$ have reported the Sephadex G-100 chromatography of albumin, globulin, prolamin and glutelin eluted from defatted rice powder. Glutelin fraction showed a single peak being passed through the column in the void volume. Sawai and Morita ${ }^{2}$ have reported an advanced method to obtain chemically pure glutelin with very little contamination of nucleic acid and carbohydrate from rice endosperm and investigated chemical and physicochemical properties of S-cyanoethyl glutelin in order to obtain information on the gross-structure of glutelin. They obtained only one peak in Sephadex G-200 gel filtration. As the average molecular weight of glutelin has been considered to be about two to three millions, it is quite possible that the purified glutelin is still separated into several components of macromolecules. The present communication concerns with the separation of three components from rice glutelin by Sepharose 2B gel filtration, which can separate molecules and particles up to molecular (particle) weight of several millions.

To prepare crude glutelin fraction, powdered milled rice was extracted first with water (albumin) five times, then with $1 \mathrm{M}$ sodium chloride (globulin) five times and finally with $70 \%$ ethanol (prolamin) five times successively by means of centrifugation, $3000 \times g$, for 30 min. The residue was shaked for $30 \mathrm{~min}$ with a volume of $0.1 \mathrm{~N}$ sodium hydroxide solution five times its weight, and centrifuged

1) E. P. Palminao, A. M. Almazan and B. O. Juliano, Cereal Chem., 45, 1 (1968).

2) H. Sawai and Y. Morita, Agr. Biol. Chem., 32, 76 (1968); idem., ibid., 32, 496 (1968). at $46,000 \times g$, for $30 \mathrm{~min}$. The combined supernatant was adjusted to $\mathrm{pH} 5.6$ with $0.1 \mathrm{M}$ acetic acid and the precipitate was collected by centrifugation, $400 \% g$, for $5 \mathrm{~min}$. It was repeated three times.

The crude glutelin was dissolved in a small volume of $0.1 \mathrm{~N}$ sodium hydroxide solution and dialyzed overnight against $0.05 \mathrm{M}$ tris (hydroxymethyl) aminomethane (Tris) buffer, $\mathrm{pH} 9.8$, containing $4 \mathrm{M}$ urea. The insoluble substances produced were removed by means of centrifugation, $46,000 \times \mathrm{g}$, for $30 \mathrm{~min}$. The dialyzed preparation gave a single peak in Sephadex G-200 gel filtration. This was submitted to the gel filtration on a Sepharose 2B column in $0.01 \mathrm{M}$ Tris buffer, $\mathrm{pH} 9.7$ containing $4 \mathrm{M}$ urea as the solvent. As shown in Fig. 1, the gel filtration gave three distinct peaks, $\mathrm{P}-1, \mathrm{P}-2$ and $\mathrm{P}-3$, which were tentatively designated according to their elution order. Molecular weights of each fractions are presumed to be more than $20 \sim 30 \times 10^{6}$ for $\mathrm{P}-1$, and less than $2 \times 10^{6}$ for $\mathrm{P}-3$. $\mathrm{P}-2$ must be an intermediate of both fractions. ${ }^{3,4}$ Fractions under each peaks were individually combined and their protein contents were measured. Relative amounts of protein in these three components was $27.3 \%$ in $\mathbf{P}$ $1,59.7 \%$ in $\mathrm{P}-2$ and $13.6 \%$ in $\mathrm{P}-3$.

The existence of three components was confirmed by rechromatography; each component was concentrated by means of isoelectric precipitation and dialyzed against distilled water. It was redissolved in small

3) S. Hjerten, Biochim. Biophys. Acta, 79, 393 (1964).

4) S. Bengtsson and L. Philipson, ibid., 79, 399 (1964). 


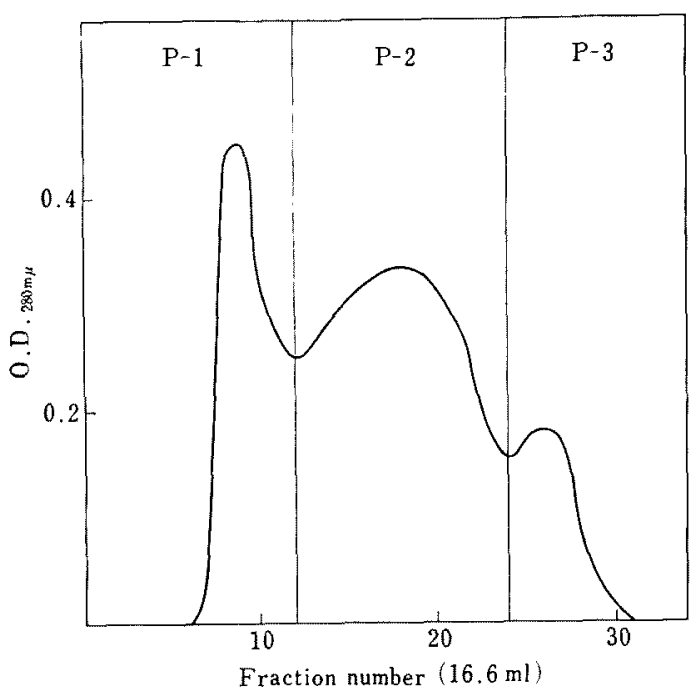

FIG. 1. Elution Curves from Sepharose $2 B(5 \times 23$ $\mathrm{cm}$ ) of Rice Glutelin.

Solvent: $0.01 \mathrm{M}$ Tris buffer, $\mathrm{pH} \mathrm{9.7,} \mathrm{contain-}$ ing $4 \mathrm{M}$ urea.

Flow rate: $1 \mathrm{ml} / \mathrm{min}$.
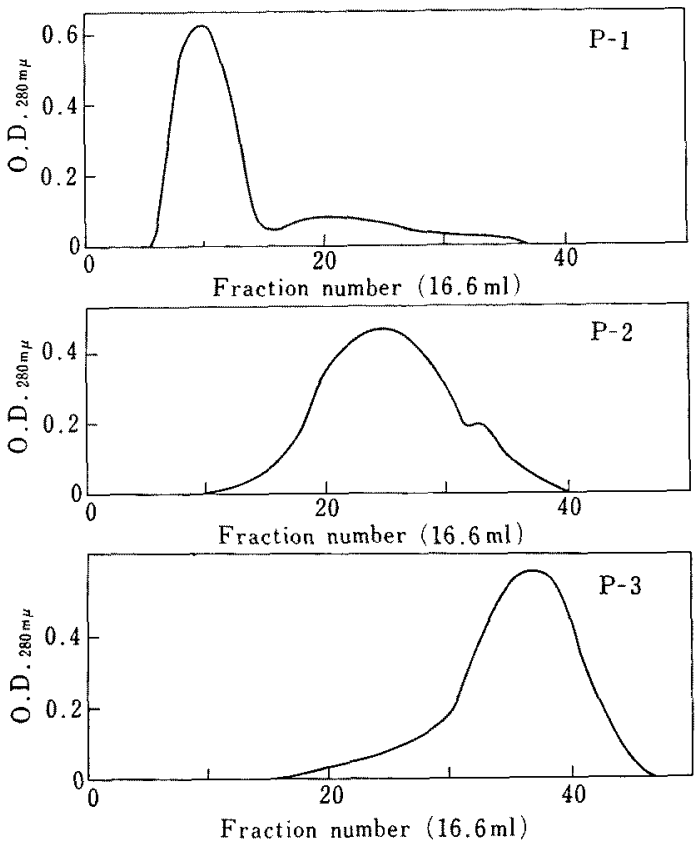

FIG. 2. Elution Curves from Sepharose $2 B$ of Each Separated Component of Rice Glutelin.

Conditions were the same as in Fig. 1. amounts of $0.1 \mathrm{~N}$ sodium hydroxide and dialyzed against the same Tris buffer. Figure 2 shows the rechromatographic patterns of each component. Each component showed a single main peak, though some contaminations from the other components could not be avoided.

Using the fractions eluted at around the main peak, the chemical analysis of each component was performed (Tables I and II). These purified components contained more phosphorous and carbohydrate than the purified preparation prepared by Sawai and Morita. $^{21} \mathrm{P}-1$ component seemed to have different constituents from $\mathrm{P}-2$ and $\mathrm{P}-3$. Amino acid compositions were also different in several amino acids among the fractions. The ultraviolet absorption spectra of each component in alkaline solution are shown in Fig. 3. $\mathrm{P}-2$ and $\mathrm{P}-3$, similar to original glutelin, exhibited a maximum at $291 \mathrm{~m} \mu$ and a minimum at $274 \mathrm{~m} \mu ; \mathrm{P}-1$, however, exhibited a quite different spectrum.

Solubility of each component into the buffer solutions of various $\mathrm{pH}$ values ranging from 1.84 to 10.28 (sodium citrate-HCl buffer for $\mathrm{pH} 1.84 \sim 3.50$, McIlvaine buffer for $\mathrm{pH} 3.50 \sim$ 8.78 and $\mathrm{Na}_{2} \mathrm{CO}_{3}-\mathrm{H}_{3} \mathrm{BO}_{3}-\mathrm{KCl}$ buffer for $\mathrm{pH}$

Table I. Phosphorus and Carbohydrate ConTENTS OF EACH COMPONENT SEPARATED From Rice GLUTELIN

\begin{tabular}{cccc} 
& Phosphorus & Pentose & Hexose \\
\hline P-1 & $36 \mu \mathrm{g}$ & $638 \mu \mathrm{g}$ & $1290 \mu \mathrm{g}$ \\
P-2 & 74 & 173 & 660 \\
P-3 & 75 & 270 & 670 \\
\hline
\end{tabular}

The values were calculated to $100 \mathrm{mg}$ of protein. Phosphorus was determined by Allen's method." Pentose and hexose were determined following to the combination of the Bial and the Tillman reactions. ${ }^{6,7}$

5) R. J. L. Allen, Biochem. J., 34, 858 (1940).

6) W. Mejbaum, Z. Physiol. Chem., 285, 117 (1937).

7) S. P. L. Sorensen and N. Haugaard, Biochem. Z., 260, 247 (1933); D. M. Surgenor, L. E. Strong, H. L. Taylor, R. S. Gordon, Jr. and D. M. Gibson, J. An. Chem. Soc., 71, 1223 (1949). 
Table II. Amino Acid Composition of EACH COMPONENT OF Rice Glutelin

\begin{tabular}{lcccc}
$\begin{array}{c}\text { Amino } \\
\text { acids }\end{array}$ & $\begin{array}{c}\text { Original } \\
\text { glutelin }\end{array}$ & $\begin{array}{c}\text { P-1 } \\
\text { fraction }\end{array}$ & $\begin{array}{c}\text { P-2 } \\
\text { fraction }\end{array}$ & $\begin{array}{c}\text { P-3 } \\
\text { fraction }\end{array}$ \\
\hline Ala & 4.5 & 4.1 & 4.3 & 4.5 \\
Asp & 9.7 & 9.0 & 10.0 & 10.6 \\
Arg & 8.2 & 9.7 & 11.6 & 11.6 \\
Cys & 0 & 0 & 0 & 0 \\
Glu & 17.0 & 15.3 & 17.3 & 15.6 \\
Gly & 4.3 & 4.1 & 4.4 & 4.2 \\
His & 3.8 & 4.9 & 3.5 & 3.6 \\
Ileu & 4.1 & 4.2 & 4.6 & 4.7 \\
Leu & 9.4 & 12.4 & 8.3 & 9.0 \\
Lys & 5.3 & 8.0 & 4.3 & 4.4 \\
Met & 1.0 & 0.8 & 1.4 & 0.5 \\
Phe & 5.4 & 4.4 & 6.2 & 4.3 \\
Pro & 7.8 & 9.3 & 5.7 & 7.6 \\
Ser & 5.7 & 3.3 & 5.5 & 5.5 \\
Thr & 3.1 & 2.3 & 3.5 & 3.4 \\
Try & trace & trace & trace & trace \\
Tyr & 2.7 & 1.0 & 2.6 & 1.8 \\
Val & 5.6 & 4.3 & 5.1 & 7.2 \\
NH & 2.4 & 2.9 & 1.7 & 1.5 \\
& & & &
\end{tabular}

Each component was hydrolyzed with $6 \mathrm{~N} \mathrm{HCl}$ in a sealed glass tube for $24 \mathrm{hr}$ at $110^{\circ} \mathrm{C}$. The hydrolyzate was analyzed its amino acid contents by a amino acid analyzer, Hitachi Model KLA-3B. The values were calculated as per cent of total amino acids found.

$8.78 \sim 10.28$ were used) having ionic strength of 0.24 differed from one another; $\mathrm{P}-1$ did not dissolve at any $\mathrm{pH}, \mathrm{P}-2$ did not dissolve at $\mathrm{pH} 4 \sim 6$ and $\mathrm{P}-3$ did not dissolve at $\mathrm{pH}$ $2 \sim 4$. Urea was added to each solution increasing its concentration from $2 \mathrm{M}$ to $8 \mathrm{M}$. Solubility of $\mathrm{P}-1$ did not increase with increasing urea concentrations, $\mathrm{P}-2$ became soluble at $\mathrm{pH} 4 \sim 6$ when urea concentration was over $6 \mathrm{M}$, and $\mathrm{P}-3$ component became soluble covering whole $\mathrm{pH}$ range when urea concentration was over $4 \mathrm{M}$. Changes in solubility and viscosity of each component in

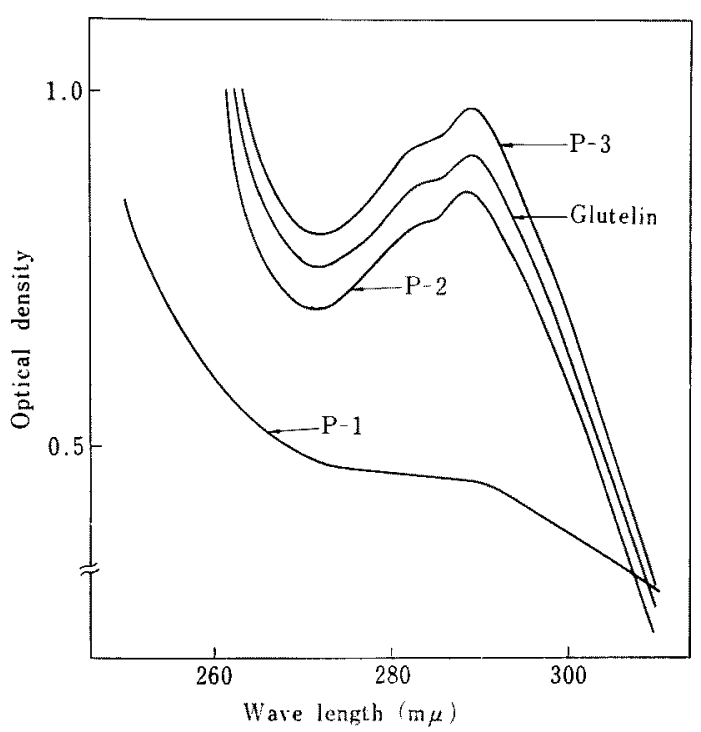

FIG. 3. Ultraviolet Absorption Spectra of Each Component of Rice Glutelin.

alkaline solution with increasing alkaline concentration were also examined. P-1 component was somewhat different from the others; it seemed to be quite labile and easy to become insoluble in alkaline solution.

It is quite probable that $\mathrm{P}-1$ is a denatured component occured in the separation procedures. As $\mathrm{P}-2$ and $\mathrm{P}-3$ components does not give rise the $\mathrm{P}-1$ component in the elution patterns of their rechromatographies, there must exist initially a component that gives $\mathrm{P}-1$ in the gel filtration pattern on Sepharose $2 \mathrm{~B}$, becomes insoluble and to exhibit different properties during or after separating and purifying procedures. Further investigation is now in progress.

This report was presented at the 43rd general meeting of Society of Fermentation Technology, November, 1968. 